\title{
Utilization of Edamame Bean Flour (Glycine Max L. Merr) in Making of High Protein and Low Sugar Cookies
}

\author{
Melanie Cornelia ${ }^{1, *}$, Ignatius Steven Lianto ${ }^{1}$ \\ ${ }^{I}$ Department of Food Technology, Faculty of Science and Technology, \\ Pelita Harapan University, UPH Tower, B Building, Karawaci, Tangerang \\ *Coresponding author. Email : melanie.cornelia@uph.edu
}

\begin{abstract}
Cookies was a pastry made from wheat flour that contains a high amount of fat with the firm and crispy texture. Wheat flour was one of many imported products in Indonesia, while there were still a lot of raw foods that can be made into flour, one of them was edamame flour which can be made from edamame beans. Therefore, the substitution of edamame flour into wheat flour will be researched in the making of cookies. The first aim of this research was to determine the best condition in making edamame flour in physical and chemical characteristics, which will be used in the making of cookies with the ratio of edamame flour: wheat flour 50\%:50\%, 33\%:67\%, 25\%:75\%, and 20\%:80\%. Each ratio will be combined with refined cane sugar and coconut sugar. The results showed that the yield of edamame flour was $23,32 \%$ with yellowish-green color that have characteristic $7.17 \%$ water, $36.15 \%$ protein, $20.14 \%$ fat, $3.80 \%$ ash, $32.74 \%$ of carbohydrates, and $191.57 \%$ water absoption ability. The best cookies formulation was made of edamame flour: wheat flour ratio 50\%: 50\% and refined fine sugar. This cookies have reddish-yellow color with 63.17 lightness, $991.46 \mathrm{~g}$ hardness, 9.85 spread ratio which has proximate analysis $4.18 \%$ water, $13.72 \%$ protein, $30.70 \%$ fat, $1.26 \%$ ash, and $50.15 \%$ carbohydrates.
\end{abstract}

Keywords: coconut sugar, cookies, edamame, glycemic index, protein

\section{INTRODUCTION}

Edamame is a type of soybean that possesses many health benefits. The protein content in edamame is up to $40 \%$ with fat (without cholesterol) in the amount of $20 \%$, carbohydrate $33 \%$ and fiber $6 \%$ [10]. On the other hand, edamame is also rich in vitamins and minerals [11]. Protein is one of the prominent components in edamame. Edamame is rich in protein and amino acids that are good for consumption by our body as they can inhibit the accumulation of cholesterol in the walls of the blood vessels. [6] stated that edamame contains a high amount of protein and 9 types of the essential amino acids our body requires. However, the utilization of edamame in Indonesia is still limited so that further research is required. Coconut sugar is a sweetener that origins from coconut juice, which has a distinct aroma and is brownish in color. One of the main advantages of coconut sugar compared to other sugars is the ability it to act as a sweetener that is healthy for the body. This is because coconut sugar has a low glycemic index, which is 35 . This value is much lower than the glycemic index of many other sweeteners. Moreover, coconut sugar also has higher nutritional content compared to other sweeteners.

\section{METHODS}

Materials and Equipments.

The raw materials were used fresh edamame beans from a plantation in Sukabumi, cane sugar and coconut sugar "Singabera, wheat flour "Segitiga Biru", margarine "Blue
Band", and chicken egg. For analysis, the chemical used were $\mathrm{NaOH} 35 \%$, boric acid $4 \%, \mathrm{~K}_{2} \mathrm{SO}_{4}, \mathrm{H}_{2} \mathrm{SO}_{4}$, selenium, HCL $0.2 \mathrm{~N}$, mixed protein indicator, and hexane. The equipment used in the research were muffle furnace, mixer, cookie cutter, oven, desiccator, analytical balance, sieve of 60 mesh, cabinet dryer, dry blender, Fomac milling machine, rotary evaporator "Buchi", Texture Analyzer TAXT, Stable Microsystem "Barnstead", chromameter "Konica Minolta".

\section{Research Procedure}

This research consisted of preliminary stage, research stage I, and research stage II. In the preliminary stage, edamame flour was made from fresh edamame beans. In research stage I, cookies production was done with ratio of edamame flour : wheat flour of 50\%:50\%, 33\%:67\%, $25 \%: 75 \%$, and $20 \%: 80 \%$, which was combined with fine sugar and coconut sugar. In research stage II, proximate analysis of best formulation cookies was done and compared to the control cookies ( $100 \%$ wheat flour).

Preliminary Research. Fresh edamame was sorted and washed with clean water. Then, the edamame beans were boiled temperature of $80{ }^{\circ} \mathrm{C}$ for 5 minutes. Afterward, the outer and inner skin of edamame was removed. The skinless edamame seeds were dried using a cabinet dryer at a temperature of $60{ }^{\circ} \mathrm{C}$ for 24 hours. Once the drying was done, size reduction was done using Fomac milling machine until the granules were quite smooth, which was then followed by size reduction using dry blender until the granules were even more smooth. In the next step the 
granules were sifted with sieve of the size 60 mesh, which resulted in the edamame flour. This edamame flour was proximately analysed and also water absorption ability, yield, and color analyzed.

Research Stage I. Cookies were made with a ratio of edamame flour and wheat flour 50\%:50\%, 33\%:67\%, 25\%:75\%, and 20\%:80\% and it was added with two types of sweetener, which was fine sugar and coconut sugar. The formulation of cookies can be seen in Table 1 [3], while the experimental design can be seen in Table 2 .

Table 1. formulation of cookies

\begin{tabular}{|l|l|}
\hline Ingredients & Amount added \\
\hline Wheat flour & 50 gram $(50 \%: 50 \%), 67$ gram \\
& $(33 \%: 67 \%), 75$ gram \\
& $(25 \%: 75 \%)$, dan 80 gram \\
& $(20 \%: 80 \%)$ \\
\hline Edamame flour & 50 gram $(50 \%: 50 \%), 33$ gram \\
& $\begin{array}{l}(33 \%: 67 \%), 25 \text { gram } \\
(25 \%: 75 \%), \text { dan } 20 \text { gram } \\
(20 \%: 80 \%)\end{array}$ \\
\hline Egg yolk & 20,74 gram \\
\hline Fat (margarine) & 53,37 gram \\
\hline Fine sugar/coconut & 46,68 gram \\
sugar & \\
\hline
\end{tabular}

Table 2. Experimental design

\begin{tabular}{|c|c|c|c|}
\hline & \multicolumn{2}{|c|}{ Types of sweeteners } \\
\hline & & $\begin{array}{l}B_{1} \text { (fine } \\
\text { sugar) }\end{array}$ & $\begin{array}{l}B_{2} \text { (coconut } \\
\text { sugar) }\end{array}$ \\
\hline \multirow{8}{*}{$\begin{array}{l}\text { Ratio of } \\
\text { edamame } \\
\text { flour and } \\
\text { wheat } \\
\text { flour }\end{array}$} & \multirow{2}{*}{$\begin{array}{l}A_{1} \\
(50 \%: 50 \%)\end{array}$} & $\left(\mathrm{A}_{1} \mathrm{~B}_{1}\right)_{1}$ & $\left(\mathrm{~A}_{1} \mathrm{~B}_{2}\right)_{1}$ \\
\hline & & $\begin{array}{l}\left(\mathrm{A}_{1} \mathrm{~B}_{1}\right)_{2} \\
\left(\mathrm{~A}_{1} \mathrm{~B}_{1}\right)_{3}\end{array}$ & $\begin{array}{l}\left(\mathrm{A}_{1} \mathrm{~B}_{2}\right)_{2} \\
\left(\mathrm{~A}_{1} \mathrm{~B}_{2}\right)_{3} \\
\end{array}$ \\
\hline & \multirow{2}{*}{$\begin{array}{l}\mathrm{A}_{2} \\
(33 \%: 67 \%)\end{array}$} & $\left(\mathrm{A}_{2} \mathrm{~B}_{1}\right)_{1}$ & $\left(\mathrm{~A}_{2} \mathrm{~B}_{2}\right)_{1}$ \\
\hline & & $\begin{array}{l}\left(\mathrm{A}_{2} \mathrm{~B}_{1}\right)_{2} \\
\left(\mathrm{~A}_{2} \mathrm{~B}_{1}\right)_{3}\end{array}$ & $\begin{array}{l}\left(\mathrm{A}_{2} \mathrm{~B}_{2}\right)_{2} \\
\left(\mathrm{~A}_{2} \mathrm{~B}_{2}\right)_{3}\end{array}$ \\
\hline & \multirow{2}{*}{$\begin{array}{l}A_{3} \\
(25 \%: 75 \%)\end{array}$} & $\left(\mathrm{A}_{3} \mathrm{~B}_{1}\right)_{1}$ & $\left(\mathrm{~A}_{3} \mathrm{~B}_{2) 1}\right.$ \\
\hline & & $\begin{array}{l}\left(\mathrm{A}_{3} \mathrm{~B}_{1}\right)_{2} \\
\left(\mathrm{~A}_{3} \mathrm{~B}_{1}\right)_{3}\end{array}$ & $\begin{array}{l}\left(\mathrm{A}_{3} \mathrm{~B}_{2}\right)_{2} \\
\left(\mathrm{~A}_{3} \mathrm{~B}_{2}\right)_{3}\end{array}$ \\
\hline & $\begin{array}{l}\mathrm{A}_{4} \\
(20 \%: 80 \%)\end{array}$ & $\left(\mathrm{A}_{4} \mathrm{~B}_{1}\right)_{1}$ & $\left(\mathrm{~A}_{4} \mathrm{~B}_{2) 1}\right.$ \\
\hline & & $\begin{array}{l}\left(\mathrm{A}_{4} \mathrm{~B}_{1}\right)_{2} \\
\left(\mathrm{~A}_{4} \mathrm{~B}_{1}\right)_{3}\end{array}$ & $\begin{array}{l}\left(\mathrm{A}_{4} \mathrm{~B}_{2}\right)_{2} \\
\left(\mathrm{~A}_{4} \mathrm{~B}_{2}\right)_{3}\end{array}$ \\
\hline
\end{tabular}

The making of cookies began with dry mixing of the dry ingredients that were wheat flour and edamame flour until homogeneous. Other ingredients like eggs and butter were mixed in a different container. The eggs and butter were mixed using a mixer with medium speed for 3 minutes. Then, the first formed mixture that was already homogeneous was added to sugar with the treatment based on the formulation. This mixture was stirred using the mixer with a low speed for 5 minutes. Next, the ingredients that were first dry mixed in a different container was added into the mixture and mixed using a mixer at a low speed for 3 minutes. The mixture was then moulded using a round moulder of diameter $3.2 \mathrm{~cm}$ and thickness of $0.3 \mathrm{~cm}$, putting the mixture on the baking pan and baking it at the 1400C for 20 minutes [4]. The cookies were analyzed based on the determined parameters that were water content, protein content, texture (hardness), color (lightness), spread ratio, and sensory.

Research Stage II was done to choose the best cookies formulation based on the proximate analysis and the comparison data with control (100\% wheat flour).

\section{RESULTS AND DISCUSSION}

\section{Characterization of Edamame Flour}

The proximate analysis of edamame flour can be seen in Table 3. This flour have a yield of $23.32 \%$, water absorption ability of $191.57 \%$, and a yellowish-green color.

Table 3. Edamame flour characterization result

\begin{tabular}{|l|c|}
\hline Parameter & $\begin{array}{c}\text { Edamame flour } \\
\text { (analysis result) }\end{array}$ \\
\hline Water & $7,17 \pm 0,08 \%$ \\
\hline Protein & $36,15 \pm 0,29 \%$ \\
\hline Fat & $20,14 \pm 0,45 \%$ \\
\hline Ash & $3,80 \pm 0,17 \%$ \\
\hline Carbohydrate & $32,74 \pm 0,36 \%$ \\
\hline Water absorption ability & $191,57 \pm 1,22 \%$ \\
\hline Percentage yield & $23,32 \pm 0,35 \%$ \\
\hline Color ( ${ }^{0}$ Hue) & $131,32 \pm 1,74 \%$ \\
\hline
\end{tabular}

\section{Water Content of Cookies}

Based on the statistical test using univariate analysis, the ratio of flour and the type of sweetener used significantly affect the water content $(\mathrm{p}<0.05)$ and also have interaction. The data are shown in Figure 1.

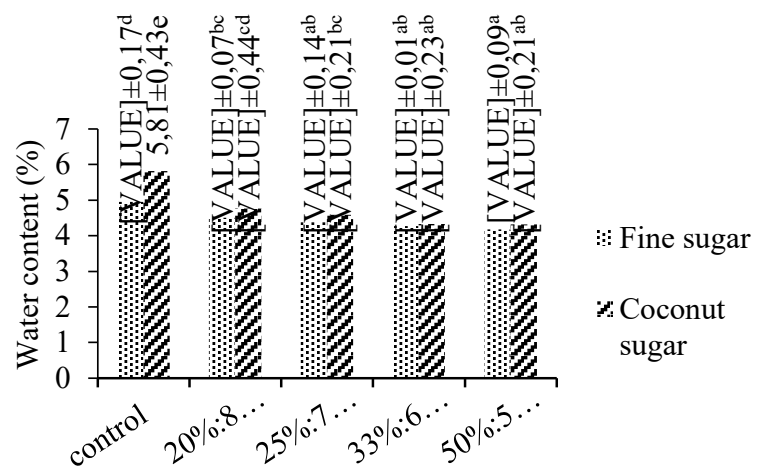

Note: Different notation shows significance at $\mathrm{p}<0.05$

Figure 1. The water content of cookies

The highest water content was shown in control cookies with coconut sugar $5.81 \pm 0.43 \%$ and that it was significantly different from the other formulations $(p<0.05)$. The increases $\%$ flour in the formulation, the water content of cookies increased. This is because the water content in wheat flour is higher than edamame flour. 


\section{Protein Content of Cookies}

The statistical test using univariate analysis indicated that the ratio of flour and the type of sweetener used significantly affect the protein content $(\mathrm{p}<0.05)$ and also have interaction. The protein content of the cookies is shown in Figure 2.

As in Figure 2, there was a significant difference $(\mathrm{p}<0.05)$ in each formulation of the cookies. The highest protein content was shown in the cookies made of ratio flour in $50 \%: 50 \%$ and coconut sugar as a sweetener $(14.62 \pm 0.09 \%)$. The fact that wheat flour is low protein 6$8 \%$ [5], while protein content of edamame flour is $36.15 \%$.

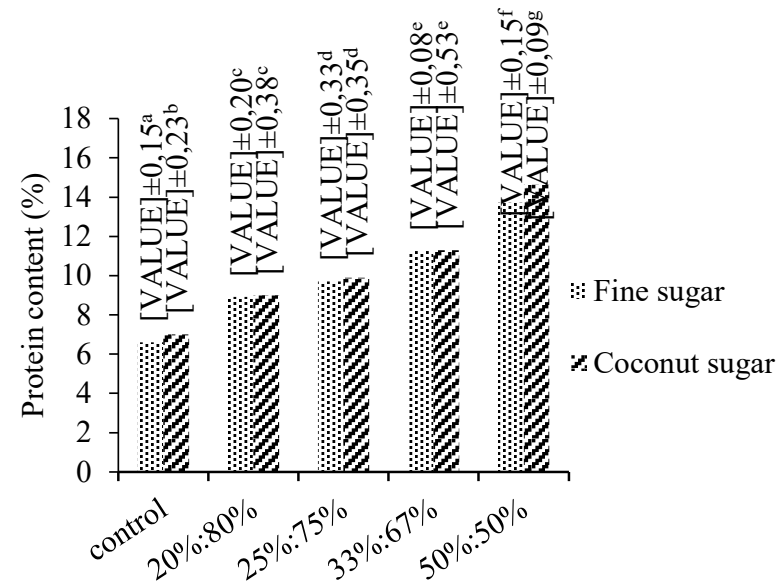

Note: Different notation shows significance at $\mathrm{p}<0.05$

Figure 2. Protein content of cookies

\section{The texture of Cookies (Hardness)}

Based on the statistical univariate analysis, the ratio of flour and the type of sweetener used did not significantly affect the hardness $(p<0.05)$ and no interaction. The data are shown in Figure 3 and Figure 4.

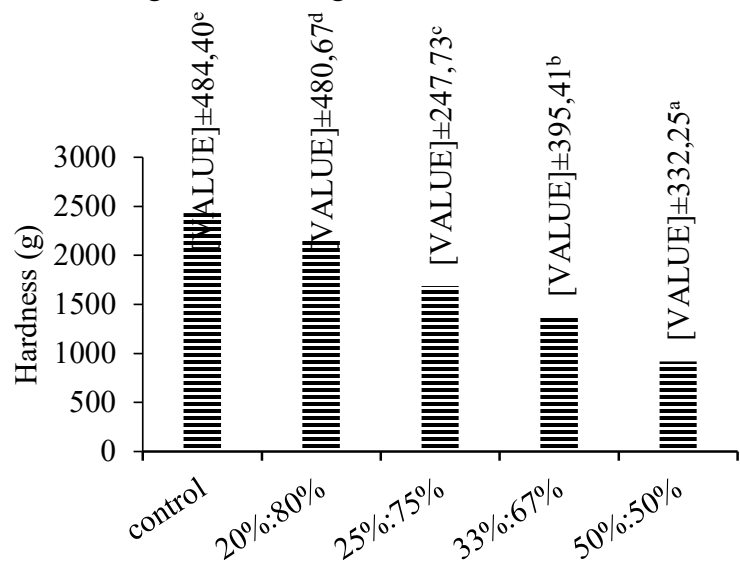

Note: Different notation shows significance at $\mathrm{p}<0.05$

Figure 3. hardness of cookies vs ratio of flour
According to Figure 3, it can be seen that each ratio of wheat was not significantly different from one another $(p<0.05)$, whereas the higher amount of wheat flour added to the formulation, the higher the hardness of cookies were [8]. This result is stated by the research [2] that control cookies had hardness higher than cookies from substitute flour. From Figure 4 it can be seen that the different types of sweetener significantly affect the hardness of cookies.

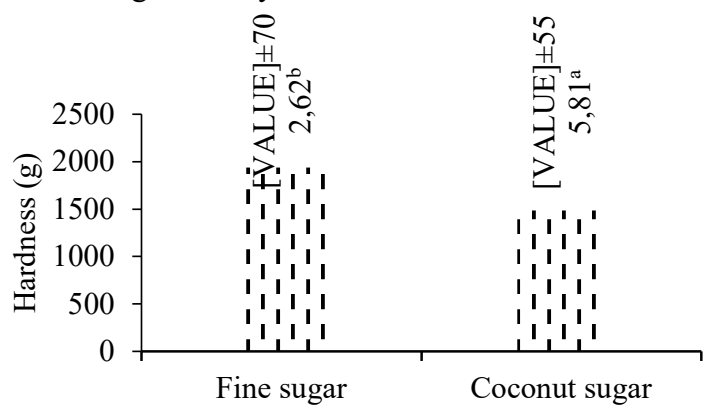

Note: Different notation shows significance at $\mathrm{p}<0.05$

Figure 4. Hardness of cookies vs type of sweetener

\section{Color of Cookies (Lightness)}

Based on the statistical test using univariate analysis, the ratio of flour and type of sweetener used significantly affect the lightness of cookies $(\mathrm{p}<0.05)$ and also have interaction. The data shown in Figure 5.

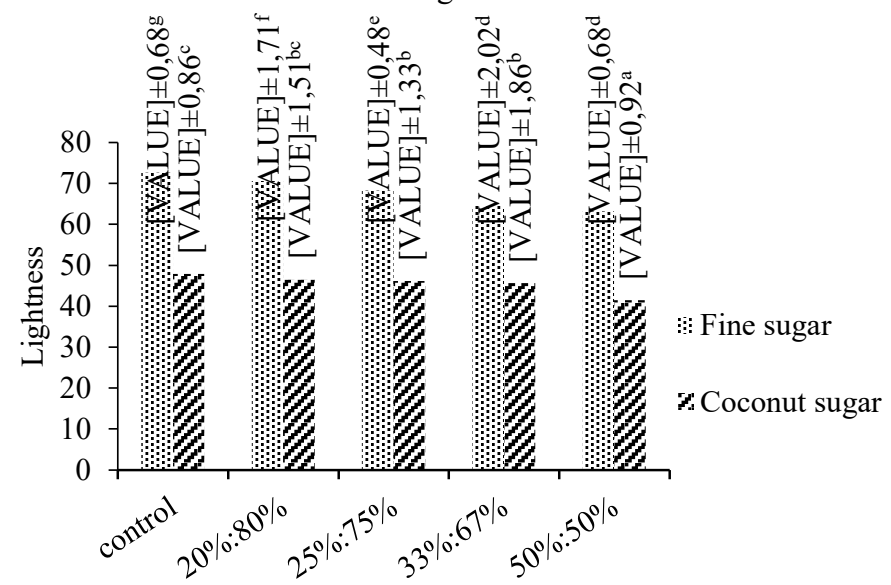

Note: Different notation shows significance at $\mathrm{p}<0.05$

Figure 5. Lightness of cookies

As can be seen in Figure 5, cookies with the highest value of lightness of $72.66 \pm 0.68$ is the control cookies made from fine sugar as the sweetener, which is significantly different $(p<0.05)$ from the lightness of cookies made from other formulation. [9] stated that as the wheat flour content increases, the color of the final product is brighter. Moreover, the white color of fine sugar also produces cookies that are brighter in color compared to coconut sugar that is slightly brown in color [7]. 


\section{Spread Ratio of Cookies}

Based on the statistical test univariate analysis, the ratio of flour and type of sweetener did not significantly $(p<0.05)$ affect the spread ratio of the cookies. Other than that, there was no interaction. It can be seen in Figure 6 and Figure 7. In figure 6 it can be seen that the $\%$ of flour used did not give a significant different towards the spread ratio.

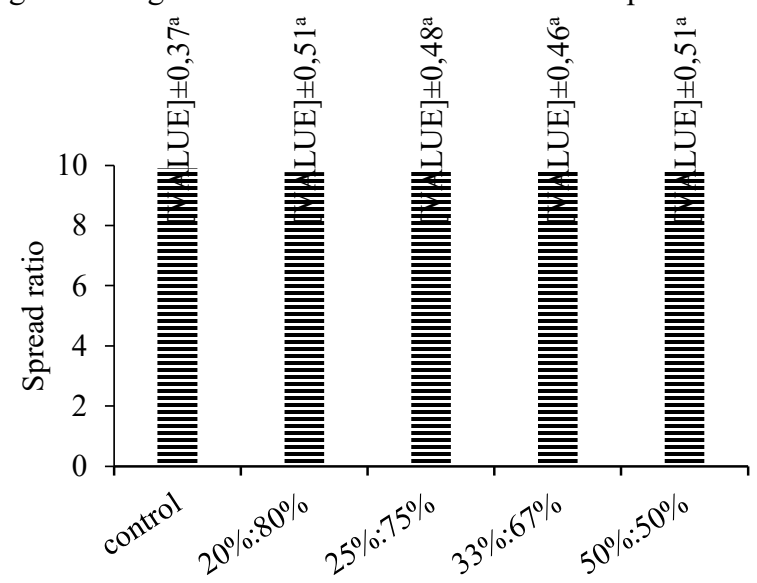

Note: Different notation shows significance at $\mathrm{p}<0.05$

Figure 6. Spread ratio of cookies (percentage of flour)

In figure 7 it can be seen that the type of sweeteners used did not give a significant difference towards the spread ratio.

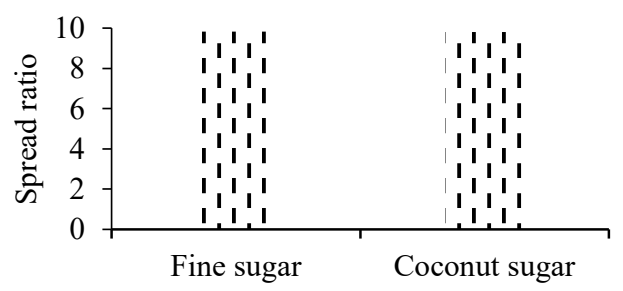

Note: Different notation shows significance at $\mathrm{p}<0.05$

Figure 7. Spread ratio of cookies (a type of sweetener)

\section{Hedonic Test of Cookies \\ Overall}

Based on the statistical test using univariate analysis, there was a significant difference $(\mathrm{p}<0.05)$ towards the ratio of flour and type of sweetener used. Moreover, there was also interaction towards the hedonic test result on the overall likeness of the cookies. The hedonic result for the overall likeness of the cookies can be seen in Figure 8.

As shown in Figure 8, the highest overall likeness of the cookies were of the cookies made from ratio of flour of $33 \%: 67 \%$ and fine sugar as the type of sweetener which have likeness value of $5.77 \pm 1.16$.. Cookies with fine sugar as the sweetener were more liked by the panellist compared to cookies made of coconut sugar.

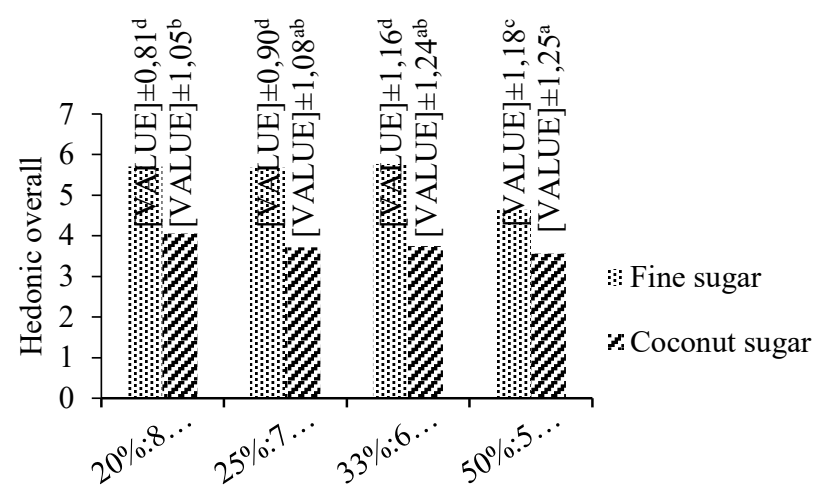

Note: Different notation shows significance at $\mathrm{p}<0.05$

Figure 8. Hedonic overall of cookies

Determination of Cookies with the Best Formulation The best formulation of cookies was chosen based on the protein content as the main parameter. Based on the analysis result, the highest protein content was found in cookies made a ratio of flour of 50\%:50\% and coconut sugar as the type sweetener. However, the acceptance of the consumer was quite poor. Therefore the chosen formulation was of the cookies presenting the second highest protein content, that was of the ratio of flour of $50 \%: 50 \%$ and fine sugar as a type of sweetener, which still falls on the category of food product high in protein content with a protein content of $13.72 \%$. This result was also supported by the fact that the overall acceptance of cookies with this formulation by the panelist was good. This formulation also was found to have water content coherent with the standard [1], brownish in color, and crunchy texture. The characterization of cookies with the best formulation is presented in Table 4 .

Table 4. Characterization of cookies

\begin{tabular}{|c|c|c|c|}
\hline & $\begin{array}{c}\text { Best } \\
\text { formulation } \\
\mathbf{( 5 0 \% : 5 0 \% ,} \\
\text { fine sugar) }\end{array}$ & $\begin{array}{c}\text { Control } \\
\mathbf{( 1 0 0 \%} \\
\text { wheat flour, } \\
\text { fine sugar) }\end{array}$ & Standard*) \\
\hline Water & $4,18 \pm 0,09 \%$ & $4,95 \pm 0,17$ & $\max 5 \%$ \\
\hline Protein & $13,72 \pm 0,15 \%$ & $6,60 \pm 0,15$ & $\min 9 \%$ \\
\hline Fat & $30,70 \pm 0,81 \%$ & $25,12 \pm 1,16$ & $\min 9,5 \%$ \\
\hline Ash & $1,26 \pm 0,12 \%$ & $0,99 \pm 0,04$ & $\max 1,5 \%$ \\
\hline $\begin{array}{c}\text { Carbo } \\
\text { hydrate }\end{array}$ & $50,15 \pm 0,67 \%$ & $62,35 \pm 1,29$ & $\min 70 \%$ \\
\hline $\begin{array}{c}\text { Total } \\
\text { calories }\end{array}$ & $531,76 \mathrm{kkal}$ & $501,84 \mathrm{kkal}$ & $\min 400 \mathrm{kkal}$ \\
\hline
\end{tabular}

*Reference: [1]Badan Standarisasi Nasional (1992)

As shown in Table 4, it can be seen that the water, protein, fat, ash content, and total calorie of the best cookies formulation chosen was in accordance with the standard. Only the carbohydrate of the cookies with the best formulation was less to the standard. 


\section{Serving Size of Best Formulation Cookies}

The serving size of cookies made of the best formulation can be seen in Table 5 .

Table 5. Serving size of cookies

\begin{tabular}{|c|c|c|c|c|}
\hline Nutrition & $\begin{array}{l}100 \\
\text { gram }\end{array}$ & $\begin{array}{l}\text { chip } \\
( \pm 2,5 \\
\text { gram) }\end{array}$ & $\begin{array}{l}\text { min } \\
\text { serving } \\
\text { size } \\
(37,61 \\
\text { gram) }\end{array}$ & $\begin{array}{l}\max \\
\text { serving } \\
\text { size } \\
(\mathbf{5 6 , 4 2} \\
\text { gram) } \\
\end{array}$ \\
\hline $\begin{array}{l}\text { Protein } \\
(\% \mathrm{w} / \mathrm{w})\end{array}$ & 13,72 & 0,34 & 5,12 & 7,67 \\
\hline Fat $(\% \mathrm{w} / \mathrm{w})$ & 30,70 & 0,77 & 11,58 & 17,38 \\
\hline $\begin{array}{l}\text { Carbohydrate } \\
(\% \mathrm{w} / \mathrm{w})\end{array}$ & 50,15 & 1,25 & 18,81 & 28,21 \\
\hline $\begin{array}{l}\text { Total calories } \\
\text { (kkal) }\end{array}$ & 531,76 & 13,29 & 199,94 & 299,94 \\
\hline
\end{tabular}

Cookies are food product that is generally consumed as a snack. Therefore, the daily consumption of cookies should be between $10-15 \%(200-300 \mathrm{kcal})$ from the total daily based of Recommended Daily Allowance (RDA) 2000 $\mathrm{kcal}$ [12]. The minimum consumption of cookies each day is 37.61 grams or equal to $15-16$ cookies, while the maximum consumption of cookies each day is 56.42 grams or equal to $22-23$ cookies.

\section{CONCLUSION}

Edamame could be made to edamame flour as a substitute wheat flour and could make increasing of protein content in product significantly. Edamame flour had $23.32 \%$ yield, water absorption ability of $191.55 \%$, and yellowish green color. Protein in edamame flour $36.15 \%$, was more higher than protein content in wheat flour that is only $8-14 \%$. Coconut sugar can also be used as a replacer of fine sugar in making cookies. Coconut sugar have an unique and distinct aroma, as well as higher nutritional than fine sugar. Cookies was made by coconut sugar as sweetener had a water and protein content higher than cookies that was made of fine sugar, color more brown and darker, spread ratio and hardness lower than fine sugar.

The best formulation of cookies was cookies made of ratio edamame flour to wheat flour $50 \%: 50 \%$ and fine sugar as the sweetener. This cookies had a total calorie of 531.76 kcal. Based on the sensory test, in overall this best formulation chosen cookies are accepted by the panelist with the value of above 4 in the scale range of 1-7.

\section{REFERENCES}

[1] Badan Standarisasi Nasional (BSN). 1992. Terms of Quality Assurance of Cookies. SNI 01-29731992. Jakarta, Indonesia.

[2] Dhankar, Poonam. 2013. A Study on Development of Coconut Based Gluten Free Cookies. International Journal of Engineering Science Invention. 2(12):10-19.

[3] Ferdinand. 2010.The Effect of Wheat Flour Substitution and Stabilizer Type in Making Sweet Potato Cookies. Thesis, University of Sumatera Utara, Medan

[4] Gunawan, Irene Erlina. 2017. Utilization of Honey and Cinnamon (Cinnamomum-burmanii) in the Making Cookies as an Alternative Snack for Diabetics. Thesis, Pelita Harapan University, Tangerang.

[5] Mayasari, Rani. 2015. Study on Characteristics of Biscuit Influenced by the Ratio of Sweet Potato Flour (Ipomea batatas L.) and Red Bean Flour (Phaseolus vulgaris L.). Thesis, University of Pasundan, Bandung.

[6] Rosiana, N. M. and Amareta, D. I. 2016. Characteristics of Edamame Yoghurt from Fermentation of Commercial Lactic Acid Bacteria Mixture Culture as a Grain-Based Functional Food. Seminar on the Results of Research and Community Service Funds BOPTN.

[7] Sari, S. M. 2016. Comparison of Sorghum Flour, Breadfruit Flour, with Peanuts and Types of Sugar towards the Characteristics of Snack Bar. Thesis, University of Pasundan, Bandung.

[8] Srivastava, S., Genitha, T. R., dan Vrijesh Yadav. 2010. Preparation and Quality Evaluation of Flour and Biscuit From Sweet Potato. Journal of Food Processing Technology. 3(12).

[9] Suryadinata, O. M. 2010. Effect of Ratio of Yellow Sweet Potato Flour to Wheat Flour on the Physicochemical and Organoleptic Properties of Sweet Biscuits. Thesis, Widya Mandala Catholic University Surabaya, Surabaya.

[10] Widati, F. dan Iteu M. H. 2012. Vegetable Soybean (Glycine Max L. Merril) as a Garden Plant. Horticulture Science and Technology. 08:25-28.

[11] Xu, Yixiang, Edward Sismour, Steve Pao, Laban Rutto, Cory Grizzard, dan Shuxin Ren. 2012. Textural and Microbiological Qualities of Vegetable Soybean (Edamame) Affected by Blanching and Storage Conditions. Journal Food Processing and Technology. 3(6):1-6.

[12] Yunarti, Endang. 2015. Sensory Evaluation and Prebiotic Components Analysis of Garut Cookies (Maranta arundinaceae L). Thesis, University of Gadjah Mada, Yogyakarta.The methods is divided into two types: social economics studies and technology \& engineering studies. 